\title{
The EU Data Protection Law Reform: Challenges for Service Trade Liberalization and Possible Approaches for Harmonizing Privacy Standards into the Context of GATS
}

\author{
Yi-Hsuan Chen ${ }^{*}$
}

\begin{abstract}
With a view to ensuring the privacy rights of EU residents, the European Commission made a proposal on the 'EU Data Protection Regulation', which has been given an extraterritorial effect when it comes to cross-border processing of EU-residents' personal data. However, the 'adequacy assessment' provided therein might lead to the EU's violations of the GATS. In the first part of this paper, an overview of the provisions of the proposed Regulation is conducted. This is followed by an examination of whether the adequacy assessment is consistent with EU's obligations under the GATS. Although there has not been a case regarding such issues in the WTO thus far, based on the preceding rationale of the Dispute Settlement Body, the author presumes that the adequacy assessment is very likely to be determined inconsistent with the abovementioned rules within the GATS. Hence, it is for the author to provide possible methods to harmonize the interests of privacy and data protection with free trade in the context of GATS in the subsequent section of this paper by utilizing the general exception clause and adapting relevant privacy standards to Article 6.5 of the GATS.
\end{abstract}

Keywords: EU - data protection - GATS - extraterritorial application - domestic regulation - adequacy assessment harmonization

\section{INTRODUCTION}

In 2012, the European Commission (hereinafter the "EU Commission") proposed a significant reform to the EU data protection legal framework, which aims at strengthening EU citizens' individual rights to personal data protection. Once adopted, the "General Data Protection Regulation" " (hereinafter the "Regulation") would replace the current Data Protection Directive $^{2}$ (hereinafter the "Directive") and could be generally applied in all EU Member States. ${ }^{3}$ Under such reform, the national authorities of the Member States would no longer be entitled to choose the forms and methods that are the most suitable for the implementation of the data protection law. Therefore, the Regulation could eliminate the divergences between the Member States when it comes to the enforcement of data protection legislation.

In order to ensure the data privacy rights of EU residents, the proposed Regulation would also be applicable to a controller not established in the territory of the EU that processes the personal data of subjects residing in the EU. Penalties and severe administrative sanctions would be imposed on those who violate the Regulation. However, judging from an international trade perspective, the provisions that regulate the transfers of personal data to third countries might lead to certain violations of EU's

International Law LL.M., Soochow University, Taiwan.

Commission Proposal for a Regulation of the European Parliament and of the Council on the Protection of Individuals with regard to the Processing of Personal Data and on the Free Movement of Such Data, COM(20I2) II final (25 January, 20I2).

Council Directive 95/46 OJ 1995 L28I/3I.

3 Commission Proposes a Comprehensive Reform of the Data Protection Rules, <http://ec.europa.eu/justice/newsroom/data-protection/news/I20I25_en.htm>, accessed 30 October 2015. 
obligations under the General Agreement on Trade in Services (GATS). To begin with, the adequate level of protection assessment (hereinafter "adequacy assessment") provided in Article 4I of the Regulation might result in the imposition of trade barriers for countries that are deemed "inadequate" by the EU Commission.

In addition, for a country where the EU Commission has taken no decision as to whether it offers an adequate level of protection, its controllers or processors that are to conduct cross-border transfer activities of EU residents' personal data must prove that appropriate protective measures were taken. This would not only place an extra burden on the controllers and processors, but also lead to the modification of competition conditions for such data controlling and processing service suppliers. As a member of the WTO, the EU is obligated to comply with the GATS. Nonetheless, the question arises, does this indicate that other important values should be forgone when it comes to the pursuit of free trade? The author thus endeavours to strike a balance between free trade and the right to privacy within the context of the GATS.

In the first part of this paper, an overview of the provisions in the proposed Regulation is conducted; this is followed by an examination of whether the adequacy assessment is consistent with EU's obligations under the GATS. Although there has not been a case regarding such issues in the WTO thus far, based on the preceding rationale of the Dispute Settlement Body, the author presumes that specific provisions in the Regulation are very likely to be determined inconsistent with the GATS. Hence, in the next section, the author intends to provide feasible means for the harmonization of free trade and privacy within the context of GATS. Lastly, some remarks conclude this paper.

\section{THE GENERAL DATA PROTECTION REGULATION PROPOSAL}

With the aim of ensuring the right to privacy of its people and to further promote global recognition of data protection rights, in 20I2, the EU Commission made a proposal to reform the EU data protection regime and thereby took theEU data protection legislation to a new level by expanding the law's scope of application. ${ }^{4}$

(I) An overview of the proposed Regulation

The proposed Regulation contains eleven chapters. Chapters I to IV set out the principles, definitions, the rights of data subjects, and the obligations of controllers and processors. Chapter V and VI concern the provisions on personal data cross-border transfer and the independent supervisory authorities. Chapter VII furthermore concerns the cooperation and consistency between Member States. Chapter VIII prescribes the remedies, liability and sanctions when it comes to the violation of the Regulation. The remaining chapters contain additional provisions regarding specific data processing situations among others.

\footnotetext{
4 C.Kuner, 'The European Union and the Search for an International Data Protection Framework', 2 Melbourne Journal of International Law (2014) 55-71, at 66.
} 
(2) The extraterritoriality of the proposed Regulation

Although according to the Directive, a EU Member State's law can be applied to a controller or processor not established in the EU that makes use of equipment situated on the territory of the said Member State (unless such equipment is used merely for transit), the scope of the proposed Regulation is even broader and has an extraterritorial effect. Instead of requiring the utilization of equipment within the EU borders, such extraterritoriality could be imposed on a controller or processor established outside the EU, whenever the data processing activities regard "the offering of goods or services to such data subjects" or "the monitoring of their behaviour."'Penalties and fines up to I million Euros could be imposed on those who violate the provisions of Chapter $\mathrm{V}$ on the transfer of personal data to third countries. ${ }^{6}$

(3) The adequacy assessment

Article 4I of the Regulation provides that any data transfer of personal data is prohibited where the EU Commission has decided that a third country does not ensure an adequate level of protection. ${ }^{7}$ As for places where the EU Commission has taken no decision, a controller or processor would have to prove that appropriate safeguards have been provided for the protection of such data in a legal binding instrument or have obtained prior authorization in the absence of the abovementioned instrument. ${ }^{8}$

To date, the EU Commission has not determined any country inadequate on its level of data protection; however, on 6 October 2015, the European Court of Justice ruled the EU Commission's decision'on the 'Safe Harbour Agreement' invalid. ${ }^{\circ}{ }^{\circ}$ The agreement was concluded in 2000 by the US and EU to provide a streamlined approach for the US companies to comply with the Directive, and the conclusion of such agreement also reflected the EU Commission's approval to the adequacy of US's data protection level. ${ }^{\text {II }}$ The recent ruling of the ECJ invalidated the said EU Commission approval, indicating the US's level of data protection inadequate. ${ }^{\mathrm{I} 2}$ According to both the Directive and proposed Regulation, EU residents' personal data shall be prohibited from transferring to the US.

\footnotetext{
The Regulation, supra n.I, Art. 3.2.

Ibid Art. 78, 79.5(f) and 79.6(1).

Ibid Art. 4I.I, 4I.5, 41.6.

Ibid Art. 42, 43.

Commission Decision 2000/520/EC of 26 July 2000, OJ 2000 L 215/7.

See generally Judgement in Maximillian Schrems v Data Protection Commissioner, C-362/14, EU:C:2015:650.

II Export.Gov: U.S.-EU Safe Harbor Overview, http://www.export.gov/safeharbor/eu/eg_main_oI8476.asp, accessed 3I

${ }^{12}$ Although the consequence of this judgment is that the Irish supervisory authority is requested to re-examine the complainant's complaint and decide whether transfer of the data of Facebook's EU users to the US should be suspended on the ground that the US does not provide an adequate level of personal data protection, the ECJ had already pointed out several factors and loopholes of the Safe Harbour Agreement that would very likely lead the decision to a direction that is
} October 2015 . not in favour of the US. 
Consequently, business transactions and data flows between the two countries would be impacted, resulting in the creation of trade barriers.

\section{REVIEWING THE ADEQUACY ASSESSMENT WITHIN THE CONTEXT OF GATS: CONSISTENCY TEST}

As mentioned, the adequacy assessment was established to strengthen EU residents' privacy rights, such as the right for people to not transfer their data under the mass surveillance conducted by the US National Security Agency or 'the right to be forgotten' as it was discussed in the Google Spain case. ${ }^{\mathrm{I}}$ Yet in another sense, such a Regulation could be an obstacle to the facilitation of international trade. In the following sections, the author examines the adequacy assessment with relevant provisions under the GATS.

(I) The scope of the GATS: A premise

Before examining whether the proposed Regulation is consistent with the obligations within the GATS, one should first make sure that the said Regulation is a measure covered by such an agreement. The Appellate Body of the Canada-Autos case pointed out that the following two key issues should be examined: Firstly, whether there is "trade in services"; and secondly, whether the measure at issue "affects" such trade in services. ${ }^{\mathrm{I}}$

In light Article r.2of GATS, "trade in services" is defined as the supply of a service in one of the four modes, namely cross-border supply, consumption abroad, commercial presence, and movement of natural persons..$^{15}$ Hence, an analysis as to whether there is a service involved and whether such service occurs through one of the four modes should be conducted. For the first tier, WTO Members often referred to the "GATS Service Sectorial Classification List (W/I20)" ${ }^{16}$ or the "UN Provisional Central Product Classification (CPC)" for the categorization of services. ${ }^{17}$ Given that data processing activities are classified to the subsector of "data processing services" under the "computer and related services" sector within $\mathrm{W} / \mathrm{I} 2 \mathrm{O}$, and the "computer related services" sector within the CPC, there is a service at issue. As for the second tier, the notion of cross-border data processing generally involves services that begin on one country's internet network and end on another, as recognized by the panel of the Mexico-Telecom case. ${ }^{18}$ Cross-border data processing thus conforms to cross border supply (mode I) of the GATS.

\footnotetext{
${ }_{13}$ See generally Judgment in Google Spain SL and Google Inc. v Agencia Española de Protección de Datos (AEPD) and Mario Costeja González, C-I3I/I2, EU:C:2014:317.

${ }_{14}$ Appellate Body Report, Canada-Certain Measures Affecting the Automotive Industry, (C9.155, WT/DSI39/AB/R (3I May 2000) [hereinafter Canada-Autos, AB Report].

Is General Agreement on Trade in Services (GATS), Art. I.2, I5 April, 1994, Marrakesh Agreement Establishing the World Trade Organization, Annex IB.

16 GATS Services Sectoral Classification List, WTO Doc MTN. GNS/W/I20 (ro July 1991).

${ }^{17}$ United Nations Statistics Division, Provisional Central Product Classification, UN Doc ST/RSA/SRAR/SER.M/77 (1991).

18 Panel Report, Mexico-Measures Affecting Telecommunications Services, 7.54, WTO Doc WT/DS24/R (2 April 2004) [hereinafter Mexico-Telecom, Panel Report].
} 
Regarding whether trade in services is affected by the measure at issue, the panel of the EC-Banana III case found the term "affected" was not only covered by "laws and regulations which directly govern the conditions of sale or purchase but also [by] any laws or regulations which might adversely modify conditions of competition between like domestic and imported products on the internal market." ${ }^{19}$ Such a broad reach was also adopted in the subsequent cases in the WTO. ${ }^{20}$ The adequacy assessment apparently would have an effect on the conditions of a foreign data processor with its service supply with EU residents' data, and should therefore pass the second requirement for the GATS to apply.

(2) The Most-Favoured Nations treatment obligation

\section{(a) Basic Concepts on the Most-Favoured Nations treatment obligation}

The Most-Favoured Nations (MFN) treatment obligation demands "non-discrimination." ${ }^{21}$ In other words, no WTO Member is to favour some countries over others. ${ }^{22}$ According to the Appellate Body of Canada-Autos, the violation of the MFN obligation lies in the less favourable treatment afforded by a Member to another Member's service or service suppliers, compared to that received by "like" service or service suppliers of other Members. ${ }^{23}$ However, what constitutes "less favourable treatment" and "likeness" of certain service or service suppliers still needs to be explained.

The Appellate Body of EC-Banana III provided guidance regarding the term "less favourable treatment", indicating that both de jure and de facto discrimination could be contained. ${ }^{24}$ As for the meaning of likeness, the GATS per se does not prescribe the determination factors; however, this can be solved by referring to interpretations on likeness under the national treatment clause in the GATT precedence. ${ }^{25}$ Apart from tariff classifications, there are three criteria, namely the "end use" of a product, "consumers' tastes and habits", and the product's "properties, nature and quality", that could also serve as determination factors. ${ }^{26}$

19 Panel Report, European Communities-Regime for the Importation, Sale and Distribution of Bananas, 7.280-282, WT/DS27/R (22May 1997) [hereinafter EC-Banana III, Panel Report].

20 M. Matsushita et al., The World Trade Organization: Law, Practice, and Policy $\left(2^{\text {nd }}\right.$ ed., Oxford University Press, 2006), at 613-615.

${ }_{21}$ Understanding the WTO- Services: Rules for Growth and Investment, <https://www.wto.org/english/thewto_e/whatis_e/tif_e/agrm6_e.htm>, accessed I November 2015 .

${ }_{22}$ GATS, Art. 2.I.

23 Canada-Autos, AB Report, I7I.

24 See Appellate Body Report, European Communities-Regime for the Importation, Sale and Distribution of Bananas, 229-234, WT/DS27/AB/R (9 September 1997) [hereinafter EC-Banana III, AB Report].

${ }^{25}$ Art. 3.4 of the GATT prescribes that "The products of the territory of any contracting party imported into the territory of any other contracting party shall be accorded treatment no less favourable than that accorded to like products of national origin in respect of all laws, regulations and requirements affecting their internal sale, offering for sale, purchase, transportation, distribution or use.[...]." As one can see, both Art. 3.4 of the GATT and Art. 2.I of the GATS contain the same wording, "like", and if one further refers to Art. 3I.I of the Vienna Convention on the law of Treaties, "a treaty shall be interpreted in good faith in accordance with the ordinary meaning to be given to the terms of the treaty in their context and in the light of its object and purpose." Therefore, the concept adopted in Art. 3.4 of the GATT could be borrowed as one intends to make interpretations within Art. 2.I of the GATS.

26 Report of Appellate Body Reports, <https://www.wto.org/english/tratop_e/dispu_e/repertory_e/nI_e.htm>, accessed 5 November 2015 . 


\section{(b) MFN analysis on the adequacy assessment}

The issue of "likeness" can be easily solved in our current case. In order to examine whether "likeness" exists, one has to confirm what the two groups of subjects for comparison are. In our current case, the subjects are (i) services or services suppliers from "a country that has been deemed adequate on the level of data protection by the EU Commission" and (ii) services or services suppliers from "a country that has been deemed inadequate on its level of data protection "or where "the EU Commission has not yet made a decision on its level of protection". Given that the services referred to in the two groups are basically the same, i.e. data processing services, and the service suppliers of each group provides the same data processing services, "likeness" does exist between the services and services suppliers from the two groups of countries. The adequacy assessment directly grants the services and service suppliers from countries that are deemed adequate the right to transfer data; ${ }^{27}$ however, those from countries that are deemed inadequate or those who are undecided do not enjoy such treatment. Even though suppliers from a country lacking a decision by the EU Commission regarding its data protection level can provide proof that appropriate safeguards have been taken in terms of crossborder data processing, ${ }^{28}$ so that they could provide such services to EU residents, the requirements of providing proof stipulated in Article 42 of the Regulation would still impose extra burdens and costs on for those suppliers. Therefore, the adequacy assessment consequently modifies the competition conditions for the latter and would lead to EU's violation of the MFN obligation.

\section{(3) The domestic regulations obligation}

\section{(a) Basic Concepts on the domestic regulations obligation}

Article 6.I of the GATS demands that a Member's measures of general application be applied in a "reasonable", "impartial”, and "objective" manner. In fact, the aforementioned terms reflect the value of due process, ${ }^{29}$ which is meant to improve the consistency and predictability of measures that could be arbitrarily imposed on foreign service suppliers. Regarding the term "reasonable", the panel of the US-COOL case defined it as "in accordance with reason", "not irrational or absurd", "proportionate", "sensible", and "within the limits of reason, not greatly less or more than might be thought likely or appropriate." ${ }^{\circ}$ Moreover, in the China-Raw Materials case the term "impartial" was defined as "not partial; not favouring one party or side more than another; unprejudiced, unbiased, fair." ${ }^{31}$ As for the meaning of "objective", given that the WTO precedence has not yet made interpretations, the author

${ }_{27}$ So far, there are only II countries that were deemed adequate by the EU Commission. Commission Decisions on the Adequacy of the Protection of Personal Data in Third Countries, <http://ec.europa.eu/justice/dataprotection/international-transfers/adequacy/index_en.htm>, accessed 6 November 2015.

28 The Regulation, supra n.I, Art. 42.

29 A. Mitchell \& T. Voon, 'Reasonableness, Impartiality and Objectivity', In A. H. Lim \& B.D. Meester (eds.), WTO Domestic Regulation and Services Trade: Putting Principles into Practice, (Cambridge University Press, 2014) 65, at 72.

30 Panel Report, United States - Certain Country of Origin Labelling (COOL) Requirements, 7.850, WT/DS384/R, WT/DS386/R (I8 November 20II) [hereinafter US-COOL, Panel Report].

${ }_{31}$ Panel Report, China-Measures Related to the Exportation of Various Raw Materials, 7.694, WT/DS394/R, WT/DS395/R, WT/DS398/R (17 August 20II) [hereinafter China-Raw Materials, Panel Report]. 
referred to scholarly work and the Cambridge dictionary, and obtained the definition of "consistency" ${ }^{2}$ and "based on real facts and not influenced by personal beliefs or feelings." 33

(b) Domestic regulations analysis on the adequacy assessment

The proposed Regulation is a measure that could be generally applied to all cross-border data processor and controller, and thus it meets the requirement of Article 6.I of the GATS. Hence, the question arises, whether such a measure is consistent with the abovementioned characteristics of "reasonable", "impartial", and "objective"?

The literature suggests that Article 6.I of the GATS stresses a substantial "proportionality" concept regarding the term "reasonable", ${ }^{34}$ which "requires a balancing exercise between the trade restrictiveness of a measure and the policy objective." ${ }^{55}$ The objective of the adequacy assessment is to ensure EU residents' privacy. This purpose could be achieved by other approaches, such as to establish an agreement similar to the Safe Harbour Agreement, but with stronger mechanisms to ensure that the other Party would be able to abide by the EU data protection regime. The EU, however, decided to impose the most restrictive approach of prohibiting services and service suppliers from a country that has been deemed inadequate to provide cross-border services. This is thus inconsistent with the concept of "reasonable." As for the terms "impartial" and "objective", though Article 4I.2 of the Regulation prescribes that the EU Commission should give considerations to the listed elements while conducting the adequacy assessment, the guideline of how these elements should be taken into account are not clear, and leaves the EU Commission much discretion. Consequently, the adequacy assessment lacks predictability and transparency, and is thus inconsistent with the meaning of "impartial" and "objective"

\section{(4) The market access obligation}

(a) Basic Concepts on the market access obligation

Article I6.I of the GATS generally prohibits the imposition of less favourable treatment on foreign services and service suppliers than what is stipulated in a Member's schedule. Hence, it constitutes the minimum market access commitment guaranteed by a Member. Moreover, Article 16.2 contains an exhaustive list of forms of market access restrictions. In other words, unless a Member clearly includes them in its commitments, it cannot impose such restrictions.

\section{(b) Market access analysis on the adequacy assessment}

When one examines the EU schedule under the GATS, one could discover that EU's commitment of market access in the subsector of data processing shows "none", which means that EU is committed

\footnotetext{
32 Mitchell \& Voon, supra note2929.

33 Cambridge Online Dictionary: Objective, <http://dictionary.cambridge.org/dictionary/english-chinesetraditional/objective_2>, accessed roNovember 2015.

34 C. L. Reyes, 'WTO-complaint Protection of Fundamental Rights: Lessons from the EU Privacy Directive', I2 Melbourne Journal of International Law(2011) I4I-176, at I60.

35 See M. Krajewski, National Regulation and Trade Liberalization in Services (Kluwer Law International, 2003 ), at I43.
} 
to provide full market access within this subsector. Therefore, the EU would violate its obligation under Article 17.I, once the EU Commission deems the protection of a country inadequate, and prohibits its service and service suppliers to provide such services. In addition, the prohibition towards the said country would result in a zero quota restriction, which would also lead to the violation of EU's obligation under Article 16.2(a), (c) of the GATS. ${ }^{36}$

Although there are certain exception clauses in Article 44 of the proposed Regulation, ${ }^{37}$ according to the consistency test above, Articles $4 \mathrm{I}$ and 42 of the Regulation would not only modify the competition conditions for a third country and its service suppliers, but also create trade barriers and further result in EU's violation of its obligations under the GATS. However, privacy and personal data protection are also essential rights and interests that complete an individual. The author thus intends to provide feasible approaches to harmonize these two types of interests in the following section.

\section{THE HARMONIZATION OF FREE TRADE AND PRIVACY WITHIN THE CONTEXT OF GATS: POSSIBLE APPROACHES}

\section{(I) General Agreement on Information Privacy?}

The notion of the establishment of a "General Agreement on Information Privacy" under the WTO came into being in 1999. It aimed at mitigating the divergences of data protection policies between WTO Members, and to further implement universally accepted core principles in a mutually acceptable approach. ${ }^{3}$ However, it is asserted that the WTO mandate should probably be limited to "trade-related" issues, and if such mandate is overly expanded, it might lead to the legitimacy crisis of the WTO. Therefore, whether such an idea could be realized depends on the future negotiations process and outcomes under the WTO, and is thus of much uncertainty.

(2) The utilization of the general exceptions clause

The general exception clause is often claimed to justify the non-compliance of the obligations under the WTO. However, such a justification is only valid when certain conditions are met. Firstly, the measure at issue should conform to one of the individual clauses under Article i4 of the GATS. The GATS general exceptions specifically provide a clause that concerns personal data protection and privacy in Article 14 (c) subsection (ii). However, by reviewing the wording of such clause, one should notice that not all types of personal data can fall within the scope of this provision, but only those

\footnotetext{
36 Appellate Body Report, United States-Measures Affecting The Cross-Border Supply of Gambling and Betting Services, 216, WT/DS285/AB/R (Nov. I0, 2004).

37 Article 44 of the proposed Regulation provides that transfers of personal data may take place on conditions such as "the data subject has consented", "the transfer is necessary for the performance of a contract between the data subject and the controller", "the transfer is necessary for important grounds of public interest", "the transfer is necessary in order to protect the vital interests of the data subject or of another person" etc. The Regulation, supra nI, Art. 44.

${ }_{38}$ See generally J.R. Reidenberg, 'Resolving Conflicting International Data Privacy Rules in Cyberspace', 52 Stanford Law Review(1999) I315-I372 [DOI: 10.2307/1229516].
} 
with the nature of confidentiality. In other words, such personal data should also fall within the confines of information privacy ${ }^{39}$ in order to fit in the purpose of the said clause.

Secondly, given that Article I4 (c) subsection (ii) of the GATS contains the term "necessary", a "necessity" test should be conducted. According to the WTO precedence, such test had often been conducted with the "weighing and balancing test." ${ }^{\circ}$ The main factors to be taken into account include "the importance of the interest or values at stake", "the extent of the contribution to the achievement of the measures objective", and "its trade restrictiveness." If the measure passes the second tier, it shall then be consistent with the Chapeau in order to be successfully claimed. That is, the measure at issue should not "constitute a means of arbitrary or unjustifiable discrimination between countries where like conditions prevail, or a disguised restriction on trade in services." ${ }^{41}$ Although until now, there hardly has been a case that the responding party won by claiming the general exceptions clause, one could still see the interest of privacy being recognized through the substantial establishment of an exclusive clause for privacy in Article I4 (c) subsection (ii) of the GATS. Thus, the Dispute Settlement Body can make reference to such clause for the harmonization of different interests in the future.

(3) The introduction of privacy standards via Article 6.5 of the GATS

Article 6.4 of the GATS provides that a Member's qualification requirement measures be based on objective and transparent criteria. Article 6.5 of the GATS, which should be interpreted in conjunction with Article 6.4 of the GATS, further prescribes that international standards should be considered while determining whether such measures conforms to the GATS. However, as it is provided in footnote 3 of the GATS, the said international standards should be launched by international bodies whose membership is open to the relevant bodies of at least all Members of the WTO.

There are several well-known international standards concerning personal data protection, for instance the UN Guidelines for the Regulation of Computerized Personal Data Protection, the APEC Privacy Framework, and the OECD Guidelines Governing the Protection of Privacy and Transborder Flows of Personal Data. However, among these international bodies, only the OECD fits in the requirement of footnote 3 of the GATS. In fact, the OECD guidelines have also been generally adopted by countries worldwide in their domestic data protection legislation. Therefore, when the Dispute Settlement Body encounters a case concerning privacy and personal data protection in the future, the OECD Guidelines should serve as an appropriate reference.

39 The objects contained in the scope of information privacy are generally information that an individual is not willing to disclose in the public, such as medical records, criminal records, sexual life etc.

40 Appellate Body Report, Brazil-Measures Affecting Imports of Retreaded Tyres, WT/DSI35/AB/R (I2 March 200I); Appellate Body Report, Korea-Measures Affecting Imports of Fresh, Chilled and Frozen Beef, WT/DSI6I/AB/R (II December 2000).

4r GATS Art.I4 Chapeau. 
(4) Panel's right to seek information

Due to the rapid spread of electronic technology, issues concerning personal data protection could change rapidly and frequently. Article 13 of the Understanding on Rules and Procedures Governing the Settlement of Disputes(DSU) entitles the panel to seek information when it is faced with a technical case. Under such provision, the panel may consult any individual for technical advice ${ }^{42}$ or request an advisory report from an expert review group. ${ }^{43}$ Although these advisory opinions do not have a coercive effect on the panel, ${ }^{44}$ they could still provide professional insights that could assist the panel with the harmonization of different interests in its decision-making.

\section{CONCLUSION}

Despite the fact that there has not been a case regarding privacy issues in the WTO thus far, based on the preceding rationale of the Dispute Settlement Body (DSB), Articles 4I and 42 of the proposed Regulation would very likely be determined inconsistent with EU's MFN treatment, domestic regulations, and market access obligations within the context of GATS.

Nevertheless, this does not indicate that the interests of personal data protection and privacy should be abandoned in order to achieve free trade. In fact, even though the main purpose of the WTO is to promote free trade, over the past 20 years, one could observe that the DSB has been committed to harmonizing different interests with free trade while making its decisions. For instance, in the US-Tuna II case, the panel dealt with animal welfare (dolphin protection) and relating environmental issues, and further intended to strike a balance between indigenous people's traditional customs, animal welfare, and free trade in the EC-Seal Products case.

The protection of privacy and personal data concerns the well-being of a person and human dignity. The approaches mentioned above have been proposed within the framework of GATS, which aims at the promotion of free trade while taking privacy into consideration. They could thus serve as possible solutions and references for harmonization when the DSB is faced with a privacy or dataprotection-related case.

42 Understanding on Rules and Procedures Governing the Settlement of Disputes (DSU), Art. I3.I, I5 April, 1994, Marrakesh Agreement Establishing the World Trade Organization, Annex 2.

43 Ibid Art. 13.2.

44 World Trade Organization, A Handbook on the WTO Dispute Settlement System (Cambridge University Press, 2004), at 26 . 